\title{
Millions of Opportunities: An Agenda for Research in Emerging Markets
}

\author{
Rajesh Chandy $^{1} \cdot$ Om Narasimhan ${ }^{2}$
}

Published online: 19 October 2015

(C) Springer Science+Business Media New York 2015

\begin{abstract}
Much of the growth and much of the change that is happening in the world today is happening in emerging markets. In this article, we offer some evidence to suggest that the changes that are happening in emerging markets today are unprecedented - in scale, scope, and speed - in human history. We highlight some of the opportunities that exist for academic research on emerging markets phenomena and argue that a single construct underlies many of these opportunities: compressed change. We present a research agenda that focuses on two phenomena that are pervasive in emerging markets but rarely studied rigorously in developed markets: marketing by micro-entrepreneurs and consumption by marginalized populations. These phenomena offer researchers in marketing the opportunity to study new outcome variables as well as new explanatory variables. Moreover, they offer researchers the ability to link explanatory variables to outcome variables cleanly and in a manner that facilitates identification of causality.
\end{abstract}

Keywords Emerging markets $\cdot$ Marketing $\cdot$ Consumer behavior $\cdot$ Marketing strategy

Imagine a contemporary map of the world that shows GDP growth rates by country. Countries growing at more than $6 \%$

\author{
Forthcoming, Customer Needs and Solutions \\ Rajesh Chandy and Om Narasimhan contributed equally to this work. \\ Rajesh Chandy \\ rchandy@london.edu \\ Om Narasimhan \\ o.narasimhan@1se.ac.uk \\ 1 London Business School, London, UK \\ 2 London School of Economics, London, UK
}

are shaded bright green, those that are shrinking are in dark red and those growing between 0 and $6 \%$ or less are in intermediate colours of the spectrum. Maps such as these, regularly produced by the IMF among others, show some features that are by now quite familiar. Large swathes of the world are awash in green. The emerging markets of Asia, sub-Saharan Africa and (to a lesser extent) Latin America have been growing at $6 \%$ or more for the last several years. A few bits are in red, and the advanced economies are largely in orange, signifying GDP growth in the $2 \%$ range.

Evidence of this transformational growth is visible in the sleek new highways in China, in the glittering new shopping malls in Kenya, in the high-tech hospitals of Colombia, in the cranes sticking into the sky in Turkey and in the shiny but cheap 'China phone' smartphones in the hands of villagers in India. Less positive evidence of this transformation is visible in the toxic air that hangs over many cities in emerging markets, in the clogged lanes of their simmering, brimming slums and in the global warming trends that threaten to sink some countries even before their markets have fully emerged. Less tangibly, but no less importantly, this transformation is visible in the changing ways in which millions of consumers and businesspersons, some rich and many poor, aspire to things that would have been incomprehensible to their parents and predecessors.

In this article, we will explore some of the research opportunities that contemporary emerging markets offer to researchers in marketing and related management disciplines. We will first offer some historical context and compare what is happening now in emerging markets to what happened over the last two centuries in the economies of today's developed markets, which were the emerging markets of yesteryear. Next, we will highlight a primary feature of emerging markets that lies at the heart of many exciting research opportunities and speculate on reasons why this feature is the way it is. Following this, we will outline some of the unique and 
important research questions that can be addressed in emerging markets today and offer a framework for new research in the area.

Some Historical Context The world has seen transformational growth before. For instance, during the Victorian era, between 1820 and 1870, Britain went from being a middling economy on the margins of Europe to becoming an empire that covered every continent [24]. It went from being an agrarian society to becoming an industrial powerhouse. It went from being a rural economy to one characterized by teeming, dynamic (and polluted and dirty) cities. And what was the average annual growth GDP growth rate during this period of transformational growth? $1.3 \%$.

Relative to the roughly $0.3 \%$ growth that preceded the Victorian era (see Table 1), this period was indeed transformational. But those unfamiliar with economic history are generally surprised that the industrial revolution in the UK - an era that saw the emergence of a countrywide railroad system, a trans-continental telegraph system, widespread mechanization of production and previously unseen levels of movement in goods and people - grew at a rate that would be considered measly by contemporary standards. And the UK was not alone in growing at these rates. The USA went from being a marginal economy amounting to less than $2 \%$ of world GDP in 1820 to becoming an economic superpower with over $27 \%$ of world GDP by 1950 [37]. And the growth rate that made this possible? Less than $2 \%$. Similarly, Japan, the original Asian miracle economy of the twentieth century, grew at less then $2 \%$ during the same period. More generally, the average annual growth rates for developed economies until the World War II period have almost invariably been less than $2 \%$ (see Table 1). The wealth that is evident in the developed world is testament to the power of compounding: year after year of (generally sub-2 \%) GDP growth.

An economy growing at $2 \%$ per year will double in size in roughly 36 years. One growing at $7 \%$, on the other hand, will double in roughly 10 years. Indeed, even a dip in growth to $3 \%$ (an outcome that would cause alarm bells to start ringing in many emerging market capitals) would nevertheless lead to an increase in prosperity that would be dramatic by the standards of Victorian Britain.

The power of compounding is rapidly transforming many of today's emerging markets. Compared to past periods, the period of growth that the world has experienced in the last generation is unprecedented - in pace and in scale - in human history. Emerging markets already represent more than $50 \%$ of world GDP [22]. Indeed, global growth — despite ups and downs in individual countries in particular periods - is now

Table 1 GDP growth over time in developed countries

\begin{tabular}{|c|c|c|c|c|c|c|c|}
\hline & $1600-1700(\%)$ & $1700-1820(\%)$ & $1820-1870(\%)$ & $1870-1913(\%)$ & $1913-1960(\%)$ & $1960-2001(\%)$ & $1820-2001(\%)$ \\
\hline Australia & & & 3.7 & 0.9 & 1.1 & 1.8 & 2.1 \\
\hline Austria & 0.2 & 0.2 & 0.8 & 1.4 & 1.3 & 2.8 & 1.6 \\
\hline Belgium & 0.2 & 0.1 & 1.4 & 1.0 & 1.1 & 2.7 & 1.5 \\
\hline Canada & & 0.6 & 1.3 & 2.2 & 1.4 & 2.3 & 1.6 \\
\hline Denmark & 0.2 & 0.2 & 0.9 & 1.6 & 1.7 & 2.4 & 1.8 \\
\hline Finland & 0.2 & 0.2 & 0.8 & 1.4 & 2.3 & 2.9 & 1.6 \\
\hline France & 0.1 & 0.2 & 1.0 & 1.4 & 1.6 & 2.5 & 1.6 \\
\hline Germany & 0.1 & 0.1 & 1.1 & 1.6 & 1.6 & 2.2 & 1.6 \\
\hline Greece & 0.1 & 20.0 & 0.6 & 1.4 & 1.4 & 3.4 & 1.8 \\
\hline Ireland & 0.2 & 0.2 & 1.4 & 1.0 & 1.0 & 4.1 & 1.6 \\
\hline Italy & 0.0 & 0.0 & 0.6 & 1.2 & 1.8 & 2.9 & 1.9 \\
\hline Japan & 0.1 & 0.1 & 0.2 & 1.5 & 2.2 & 4.0 & 1.4 \\
\hline Netherlands & 0.4 & -0.1 & 0.8 & 0.9 & 1.5 & 2.4 & 1.7 \\
\hline New Zealand & & & & 1.2 & 1.4 & 1.2 & \\
\hline Norway & 0.2 & 0.2 & 0.5 & 1.3 & 2.3 & 3.0 & 1.5 \\
\hline Portugal & 0.1 & 0.1 & 0.1 & 0.6 & 1.8 & 3.8 & 1.5 \\
\hline Spain & 0.0 & 0.1 & 0.4 & 1.2 & 0.9 & 4.0 & 1.6 \\
\hline Sweden & 0.2 & 0.2 & 0.7 & 1.4 & 2.2 & 2.1 & 1.7 \\
\hline UK & 0.2 & 0.3 & 1.3 & 1.0 & 1.2 & 2.1 & 1.4 \\
\hline USA & & 0.7 & 1.3 & 1.8 & 1.5 & 2.3 & 1.7 \\
\hline $\begin{array}{l}\text { Median growth } \\
\text { of rich countries }\end{array}$ & 0.2 & 0.2 & 0.8 & 1.3 & 1.6 & 2.7 & 1.6 \\
\hline
\end{tabular}

Source: Easterly [23] 
largely powered by growth in emerging markets (International Monetary [29]). In addition to offering hope (or frustration) to millions, the growth that we witness in emerging markets today offers remarkable opportunities for novel, rigorous, and impactful research. Emerging markets offer opportunities to explore phenomena that are entirely new to the marketing discipline, as well as to better understand existing phenomena. A single construct, in our assessment, underlies many of these opportunities: compressed change. We discuss this construct in greater detail in the section below.

Compressed Change The growth that is evident in macroeconomic statistics is a manifestation of dramatic changes, powered by technology and trade, in the lives of consumers and firms. Moreover, this change has been squeezed into a very brief - by historical standards - period of time. It should not surprise us that this phenomenon is altogether unique in feel and consequence. Its consequences for research in marketing (and the social sciences at large) have, however, not been explored in much depth. Much of what follows is devoted to this task; we start with speculation on why this compressed change is happening now, followed by a deeper discussion of different aspects of compressed change. This immediately suggests a set of researchable topics, and we discuss those in some detail via examples. Because research on these topics - despite their relevance and importance to marketing - is yet to appear in top marketing journals (see [47] for an exception; also see [46]), many of the examples we highlight are from research done in other areas.

To gain perspective on the uniqueness of the current context, it helps to consider patterns in trade over time. Certainly, trade is not a new concept for humankind. But the extent of trade we witness today is a far cry from what the world witnessed just a generation ago (Figs. 1 and 2). Similarly, word about the outside world has reached communities even before humans worked out how to send smoke signals. But the extent of information flow is orders of magnitude higher today than just a generation ago [13]. Moreover, the sources of information today are often common across countries (see Table 2). Connectedness - through physical and digital means - has meant flows in information, ideas, money and people in a manner that is profoundly changing human society. While compressed change exists everywhere today, its effects are particularly dramatic in emerging markets, for at least three reasons.

First, compressed change has meant that emerging market consumers and firms are leapfrogging across multiple generations of products and technologies. For example, billions of emerging market consumers have leapfrogged landline phones: they went from never having used a phone in their lives to relying on their mobile phones for commerce, consumption and security [30]. Millions of consumers in Africa are leapfrogging grid electricity to adopt solar lamps as their source of lighting [36]. Millions of Kenyans leapfrogged bricks and mortar banking - a majority of economically active Kenyans went from being unbanked to using mobile money within a period of roughly 5 years [31]. (Who would have imagined that in 2013, slumdweller entrepreneurs in Nairobi Kenya would be more likely to use mobile money than garage-dweller entrepreneurs in Silicon Valley?). The absence of an installed base of legacy products and services is one reason why the sales takeoff of new products and services can sometimes happen far more quickly in emerging markets than in developed markets (e.g. see [31]). This renders it feasible to study the impact of such change in a relatively short interval. It also provides opportunities to study phenomena that are no longer feasible to study in developed countries, e.g. the introduction of TV [34]. In a very real sense, emerging markets offer the opportunity to be there at the origin of the change and observe its transformative effects.
Fig. 1 Total exports as a percentage of world GDP: 1820-2013, source: Ghemawat and Altman [27]

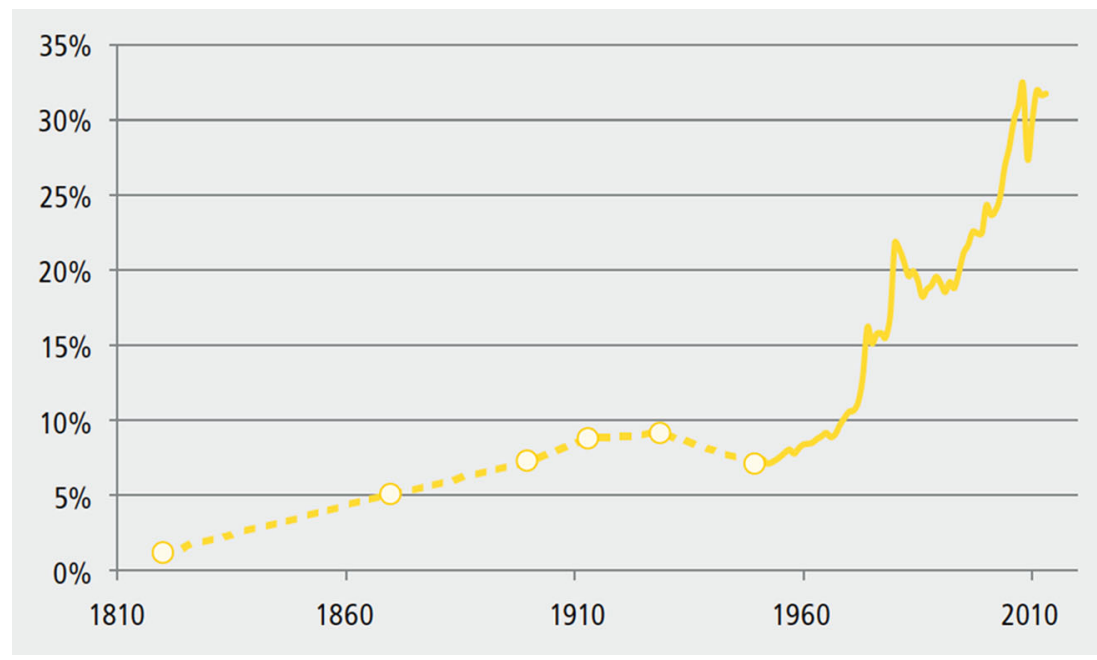


Fig. 2 Foreign direct investment as a percentage of world GDP: 1913-2013, source: Ghemawat and Altman [27]

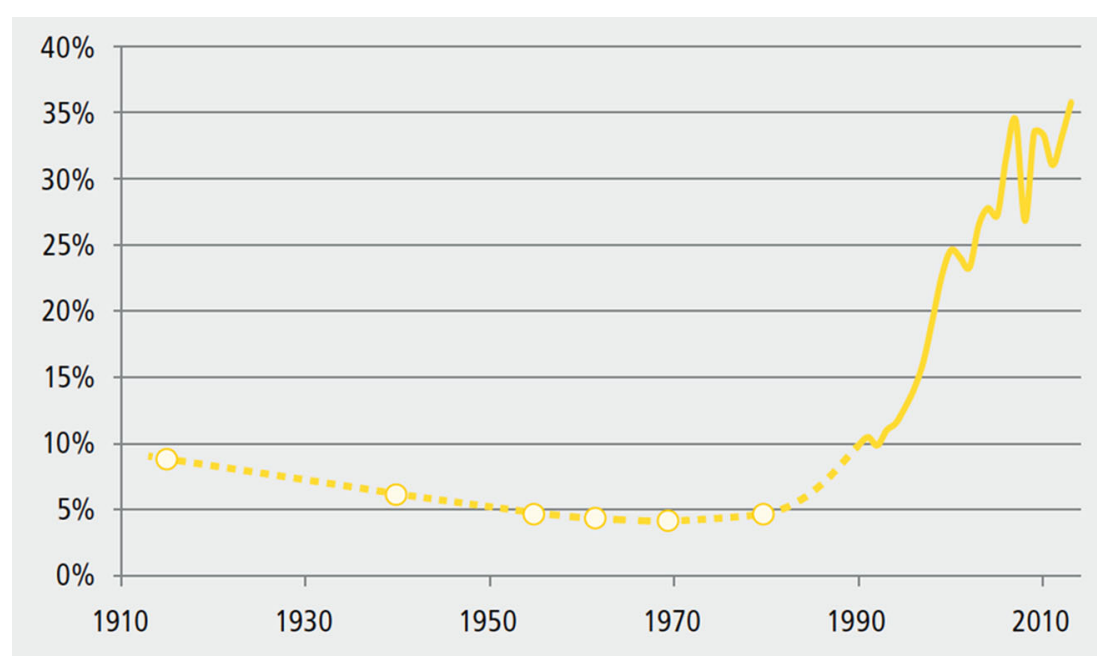

Second, compressed change has meant that many of those living in emerging markets are confronted with a multiplicity of signals: they have access to technologies, ideas and products that are new to the world, as well as those that have been familiar to those in developed markets for many years. For example, villagers suddenly have access not only to televisions and highways but also to smartphones and solar lamps. Signal multiplicity implies that the intensity of change in mindsets and behaviours is often higher among those in emerging markets than in developed markets (especially when the signals reinforce each other, as in a rural area gaining access to satellite television as well as the building of a new highway providing an urban connection).

Third, compressed change can also lead to inequality in outcomes within emerging markets. Path dependence can imply that those who received access to the sources of change relatively early can move substantially ahead of those who did not receive this access. For example, incomes are substantially higher among Indian villagers who had the good fortune of having their villages intersected by new interstate highways relative to those who live farther from the highways. Inequality in access to opportunity can exacerbate social tensions and also lead to large-scale migration from those locations that do not offer such access to those that are perceived to do so. From the point of view of research, this increased heterogeneity implies relatively large differences in interesting dependent variables (e.g. the consumption basket of someone in a village close to a new highway versus one in a village that the highway does not skirt; schooling choices for a girl child in a village that has access to cable TV versus a village that does not), in turn making effects easier to uncover and causes easier to pin down.

To fully appreciate the exciting opportunities such change provides for academic researchers, it is useful to think of three basic questions one often asks to assess the incremental contribution of any area of research: Is the outcome variable different from what has been studied before? Is the explanatory variable different from what has been studied before? Is the way in which outcome variables are linked to explanatory variables different from what has been done before? An affirmative action to any of these questions would suggest promise for those wishing to make an incremental contribution. Partly because emerging markets offer the opportunity to study entirely new populations of consumers and firms, they offer the possibility of affirmative answers to each of these questions.

In the sections below, we offer illustrative examples of research that offer templates and stepping stones for new research in marketing. In the interest of space and focus, we highlight two topics that might offer especially promising avenues for research in marketing: (1) marketing by micro-entrepreneurs, defined as those who own businesses with five or fewer employees and (2) consumption among marginalized populations such as the ultra-poor, migrants or those at a disadvantage on the basis of social or historical factors such as caste (e.g. in India), race (e.g. in South Africa), religion (e.g. in Egypt) and gender (e.g. in India, among other places). We emphasize these populations for two main reasons. First, these populations acquire outsize importance in emerging markets - even though they are not restricted solely to emerging markets. For example, Bolivians engage in entrepreneurial activity (mostly as micro-entrepreneurs) at three times the rate as Americans and five times the rate as those in the UK [14]. In Peru, $69 \%$ of urban households earning less than $\$ 2$ a day operate a non-agricultural business, and in India, one estimate puts the number of urban poor who are self-employed at $40 \%$ [6]. Most rural farmers in developing countries also fall within the definition of micro-entrepreneurs. For these reasons, the percentage of entrepreneurs in the population is substantially higher in developing countries than in developed countries. But the motivations of many developing country entrepreneurs are subsistence oriented rather than opportunity oriented. Many barely eke out a living [16]. 
Table 2 Ranking of websites accessed by country

\begin{tabular}{|c|c|c|c|c|c|}
\hline & Google & Facebook & Youtube & Yahoo & Wikipedia \\
\hline USA & 1 & 2 & 3 & 5 & 6 \\
\hline UK & 1 & 2 & 4 & 7 & 8 \\
\hline France & 1 & 2 & 3 & 5 & 8 \\
\hline Germany & 1 & 2 & 5 & 9 & 7 \\
\hline Italy & 1 & 2 & 3 & 5 & 6 \\
\hline Spain & 1 & 2 & 3 & 7 & 8 \\
\hline Poland & 1 & 2 & 4 & 17 & 7 \\
\hline Brazil & 1 & 2 & 3 & 10 & 6 \\
\hline Russia & 3 & 6 & 5 & 8 & 19 \\
\hline India & 1 & 2 & 3 & 6 & 4 \\
\hline China & 18 & - & - & - & - \\
\hline Mexico & 1 & 2 & 3 & 7 & 4 \\
\hline Turkey & 1 & 2 & 3 & 15 & 43 \\
\hline Indonesia & 1 & 2 & 3 & 13 & 5 \\
\hline Pakistan & 1 & 2 & 15 & 7 & 4 \\
\hline Bangladesh & 2 & 1 & 3 & 10 & 5 \\
\hline Egypt & 2 & 1 & 3 & 20 & 5 \\
\hline Saudi Arabia & 1 & 3 & 2 & 10 & 6 \\
\hline Iran & 1 & - & - & 10 & 2 \\
\hline Jordan & 2 & 1 & 3 & 17 & 10 \\
\hline Iraq & 2 & 1 & 3 & 9 & 4 \\
\hline Morocco & 1 & 2 & 4 & 12 & 11 \\
\hline Qatar & 1 & 2 & 3 & 7 & 5 \\
\hline Syria & 2 & 1 & 3 & 17 & 6 \\
\hline Nigeria & 1 & 2 & 4 & 11 & 3 \\
\hline South Africa & 1 & 2 & 3 & 7 & 4 \\
\hline Kenya & 1 & 2 & 4 & 7 & 3 \\
\hline Ghana & 2 & 1 & 4 & 7 & 3 \\
\hline Sudan & 1 & 2 & 3 & 12 & 4 \\
\hline Uganda & 1 & 2 & 3 & 6 & 4 \\
\hline Mauritania & 2 & 1 & 3 & 7 & 4 \\
\hline
\end{tabular}

Figures refer to the rank, in terms of unique user traffic, of each website among those accessed by users from each country. Websites ranked below 50 are listed as missing values. Source: alexa.com, accessed February 22,2015

Similarly, by commonly agreed definitions, there are roughly 1 billion ultra-poor people in the world, concentrated in South Asia and sub-Saharan Africa [7]; people classified as rural are the majority in most emerging markets, while they would be less than $5 \%$ in most of the developed world; the proportion of migrants in India's urban areas was $35 \%$ even in 2008 (NSS 2008), a number that has likely risen considerably since. Marketing research, focused as it has been on the developed world, has had little to say on any of these populations.

Second, emerging markets display extreme examples of such heterogeneity among market segments - the difference between the consumption basket of a resident of rural North
Dakota and a resident of Manhattan is much smaller than that between a resident of Nairobi and a resident of the Rift Valley. Similarly, the differences in business practices and outcomes among businesses in developed markets are much smaller than those among businesses in developing markets.

To recap, in what follows, we provide illustrative examples of research in emerging markets that can serve as pointers to both what is feasible and to the many gaps that still exist in our knowledge (see Tables 3 and 4 for a summary). We organize our discussion using the same three questions we had suggested were useful to ask to judge the contribution of any research, i.e. the novelty of the outcome variable, the novelty of the explanatory variables and the novelty of the mechanism linking the explanatory variables to outcomes. We begin with a focus on the linking mechanism because it helps clarify some of the unique possibilities that exist in the area. And as stated earlier, we try to keep our examples focused on two main populations of interest, micro-entrepreneurs and marginalized populations.

\section{New Ways of Linking Outcomes to Explanatory Variables}

Perhaps, the most exciting work in emerging markets, and one that, to us, seems to offer the most obvious research opportunities, involves new ways of letting the researcher pin down the causal relationship between variables while staying anchored to important and understudied phenomena. This is particularly topical, given the recent emphasis in marketing research on the need to precisely identify causality through means other than a laboratory experiment [44]. We note three ways in which emerging markets are providing fertile grounds for addressing causality: (1) studying phenomena from their points of genesis, (2) making use of natural experiments and (3) conducting randomized controlled trials (RCTs).

1. Studying phenomena from their points of genesis: Emerging markets offer opportunities for researchers to be present at the birth of new phenomena. This often permits a very clean measurement of 'before' and 'after', which is really the essence of identification. Excellent examples of such studies are two very influential papers by Jensen [32] and Jensen and Oster [34]. The first looks at the introduction of mobile phones in the southern Indian state of Kerala. The context is that of fishermen who venture out to sea to catch fish and come back to shore later in the day to sell their catch. The key is that they have the choice of a number of places to dock - where they go is dictated by their expectation of the demand/supply balance at any location. Jensen's focus is on the prices that fishermen realize for their produce, since the transaction price is the variable that best captures the demand/supply balance. Key to his identification is the fact that the introduction of mobile 
Table 3 Research overview

\begin{tabular}{|c|c|c|}
\hline & Outcome variables & Explanatory variables \\
\hline Marketing by micro-entrepreneurs & $\begin{array}{l}\text { - Performance: De Mel et al. [18] } \\
\text { - Differentiation: Hassan et al. [28] } \\
\text { - Impact on household welfare: } \\
\text { Banerjee et al. [7] } \\
\text { - Spillover impact on community } \\
\text { behaviour: Conley and Udry [17] }\end{array}$ & $\begin{array}{l}\text { - Information: Jensen [32] } \\
\text { - Capital: [18]; } \\
\text { - Skills: Karlan and Valdivia [35]; } \\
\quad \text { Anderson et al. [2] } \\
\text { - Infrastructure (e.g. highways): } \\
\quad \text { Dutta [21]; Ghani et al. [26] }\end{array}$ \\
\hline $\begin{array}{l}\text { Consumption by marginalized } \\
\text { populations }\end{array}$ & $\begin{array}{l}\text { - Consumption basket: Collins et al. [16]; } \\
\text { Banerjee et al. [7] } \\
\text { - Information processing and cognitive } \\
\text { load: Mani et al. [38] } \\
\text { - Adoption of socially useful } \\
\text { products/practices: Ashraf et al. [4]; } \\
\text { Gandhi et al. [25] }\end{array}$ & $\begin{array}{l}\text { - Historical events (e.g. slavery, colonization) } \\
\text { affecting current outcomes: Nunn ([42], 2013); } \\
\text { Michalopoulos and Papaioannou [39]. } \\
\text { - Marketing mix affecting adoption of socially } \\
\text { useful products/practices: Dupas [20]; } \\
\text { Miguel and Kremer [40]; Muralidharan } \\
\text { and Prakash [41] } \\
\text { - Social networks and information flows: } \\
\text { Banerjee et al. [5] } \\
\text { - Exposure, spillover effects: Jensen [33]; } \\
\text { Bernard et al. [9] }\end{array}$ \\
\hline
\end{tabular}

Table 4 Illustrative research questions

\begin{tabular}{|c|c|c|}
\hline & New outcome variables & New explanatory variables \\
\hline Marketing by micro-entrepreneurs & $\begin{array}{l}\text { - Why do some micro-entrepreneurs market better } \\
\text { than others? Why do some micro-entrepreneurs } \\
\text { perform better than others? } \\
\text { - How does the market performance of micro- } \\
\text { entrepreneurs affect the entrepreneurs' personal } \\
\text { and household consumption behaviour? } \\
\text { - How does the market performance of micro- } \\
\text { entrepreneurs affect (1) their aspirations for } \\
\text { themselves and (2) their aspirations for their } \\
\text { children? } \\
\text { - How does the market performance of micro- } \\
\text { entrepreneurs affect the aspirations and behaviours } \\
\text { of others in their community? }\end{array}$ & $\begin{array}{l}\text { - What are the constraints that prevent micro- } \\
\text { entrepreneurs from (1) engaging in better } \\
\text { marketing practices and (2) performing better? } \\
\text { - To what extent do constraints in (1) human } \\
\text { capital, (2) financial capital, (3) managerial } \\
\text { capital and (4) social capital drive differences } \\
\text { in marketing practices and performance? What } \\
\text { are the solutions to these constraints? } \\
\text { - How do the changes in the personal and household } \\
\text { lives of micro-entrepreneurs affect their } \\
\text { marketing behaviour and market performance? }\end{array}$ \\
\hline $\begin{array}{l}\text { Consumption by marginalized } \\
\text { populations }\end{array}$ & $\begin{array}{l}\text { - How does consumption change when the ultra-poor } \\
\text { become less poor? Within which elements of the } \\
\text { consumption basket do the ultra-poor increase } \\
\text { expenditures, and which do they decrease } \\
\text { expenditures when they become less poor? } \\
\text { - How do the members of marginalized populations } \\
\text { process market information? When money is } \\
\text { scarce, are consumers more likely to engage in } \\
\text { systematic processing or heuristic processing to } \\
\text { make consumption decisions? Are the poor (and } \\
\text { other marginalized populations) less likely to make } \\
\text { future oriented choices such as investments with } \\
\text { payoffs in the future (rather than the present)? } \\
\text { - To what extent are sub-optimal consumption choices } \\
\text { among the poor and marginalized populations } \\
\text { driven by (1) lack of choice alternatives, (2) lack } \\
\text { of information about choice alternatives and (3) } \\
\text { sub-optimal weighting of choice criteria? } \\
\text { - Why do some products take off more quickly among } \\
\text { the poor than others? }\end{array}$ & $\begin{array}{l}\text { - How do historical events (e.g. slavery, class, caste } \\
\text { or gender restrictions) affect contemporary } \\
\text { consumption outcomes? } \\
\text { - How do changes due to politics, migration, } \\
\text { communications or infrastructure affect } \\
\text { consumption outcomes? } \\
\text { - Why are some social marketing messages more } \\
\text { effective in changing behaviour among } \\
\text { marginalized populations? To what extent do (1) } \\
\text { monetary factors, (2) human capital and (3) social } \\
\text { and peer effects affect the success of social } \\
\text { marketing messages among marginalized } \\
\text { populations? } \\
\text { - How does exposure to (1) new populations and (2) } \\
\text { new practices affect consumption and investment } \\
\text { behaviour among marginalized populations? }\end{array}$ \\
\hline
\end{tabular}


phones was not simultaneous across all fishing villages. The clear exogenous shock, coupled with the phased manner in which it was rolled out, lets Jensen [32] pin down precisely the effect of mobile phone introduction on the distribution of transaction prices. A single graph (Fig. 3) brilliantly captures much of this story - the introduction of mobile phones led to a rapid convergence of prices, supporting the theoretical prediction of price dispersion as information becomes more symmetric. More importantly, the study clearly quantifies the improvement in social welfare that can result from the introduction of mobile phones.

A similarly path breaking study by Jensen and Oster [34] examined the effects of the introduction of cable TV on a set of villages in rural India. The authors gathered data on a host of variables relating to social attitudes and behaviour, particularly as they relate to women. The regions they studied have historically been marked by very low levels of female empowerment, as indicated by common markers of education, nutrition, autonomy, etc. Their hunch was that the introduction of cable TV would expose people in the region to a set of norms that are likely to be more progressive than those that they have historically been familiar with. The exogenous shock of TV introduction allows them to use panel data to do a fairly clean 'before/after' design and helps control for any village and time trends. They find that the status of women improved remarkably after the introduction of cable television, as measured by attitudes towards girl children (lowering of the 'son preference), increased input into household decision-making, enhanced desire for schooling and lowered tolerance for domestic violence. Studies such as these offer tantalizing glimpses of the possibilities that exist to study the impact of new technologies and new social marketing initiatives in emerging markets. Because researchers can often be present in the field even before the initiatives are introduced to the target populations, they can study - in a much more complete manner than otherwise - the impact of these initiatives on consumer, firm and societal outcomes. Moreover, they highlight how the exogenous shocks that are inherent in the compressed change we
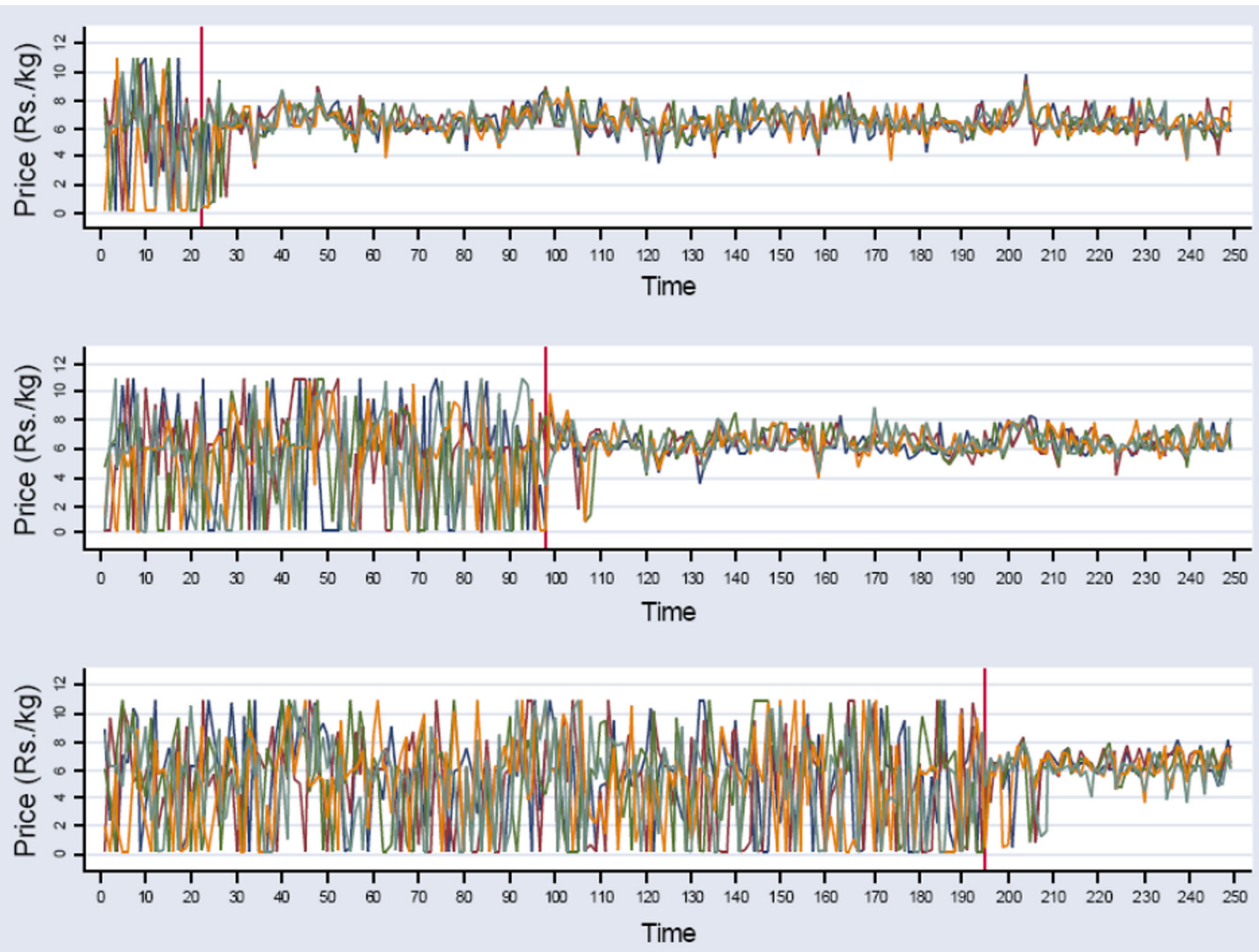

Fig. 3 Changes in price after mobile phone introduction in Kerala fishing markets. Notes: The vertical line in each graph refers to the week in which mobile telecommunications were introduced in each of three sets of fishing villages in Kerala, India. Price (in rupees per kilo) refers to the average price of sardines in the markets in each set of villages. Source: Jensen [32] 
noted earlier can help researchers cleanly identify the causal effects of social marketing initiatives. We next discuss a set of approaches that rely on such exogenous shocks to identify causality.

2. Natural Experiments: The use of natural experiments relies on the existence of an exogenous shock that has an impact on a set of outcome variables of interest. A very diverse set of exogenous shocks has been studied in previous researchconflict, elections, weather, quota laws, property rights enforcement. Again, while there have been many influential studies using natural experiments in the developed world, especially in economics and political science (e.g. [3] looks at returns to schooling exploiting the exogeneity provided by school admission date cutoffs; see [19] for a detailed treatment of natural experiments in the social sciences), this approach has special relevance to emerging markets for two big reasons.

First, the nature of compressed change is such that there are many more discrete changes in the macro environment (the multiplicity of signals referred to earlier), in turn giving rise to many opportunities for research. Second, the chances of finding a significant effect are much larger because the changes being considered generally 'move the needle' on the dependent variables to a much greater degree (this is, of course, true for the RCT case too). Thus, the construction of a paved road or the provision of electricity makes a very fundamental difference to every aspect of people's lives-how they spend their time, how much money they have to spend, how they spend their money and quite possibly attitudes and aspirations.

For instance, Dutta [21] and Ghani et al. [26] both study the impact of India's Golden Quadrilateral Program, whose purpose is to improve highways connecting India's four largest cities. This is a classic 'shock', in that there are regions that will fortuitously be benefitted by proximity to the improved highways, while there are regions that will be too far away to benefit. Indeed, both studies above find significant effects on such diverse variables as the number of manufacturing units that enter (increases with closeness to highway) to the amount of inventory held by firms (decreases with closeness to highway), to the probability of having switched suppliers (goes up with closeness to highway). There are any number of interesting marketing variables, dependent and explanatory, that can be studied even in this context. We have no idea, for instance, if the marketing tactics used by retailers changed thanks to the greater access to suppliers and customers offered by better highway access. If nothing else, how was their product assortment affected? How does the product assortment of a retailer closer to the highway differ from one further away? On the consumer side, how did the consumption basket change?

Another set of exogenous shocks that offer research possibilities arises from changes in society as a result of major political change. For example, participation by women in the labour force varies dramatically across countries: Alesina et al. [1] note that in 2000 , the female labour force participation ranged from $16.1 \%$ (in Pakistan) to $90.5 \%$ (in Burundi). Female participation in customer facing activities (which are especially relevant to marketing) is likely to be even more dramatically different across countries, given differences in what is considered the appropriate role of women in society. Exogenous changes in laws can help researchers examine the impact of changes in society on changes in marketing participation. For example, Chattopadhyay and Duflo [15] look at the impact of an Indian law that made it mandatory for one third of all village council chief posts to be reserved for women. They find that women and men differ significantly in policy preferences, with women more likely to be responsive to the concerns of women constituents; further, the presence of a woman council chief significantly increases civic participation on part of women. Does increased participation of women in political activity and civic affairs change the female participation in market facing activities as well? As laws favouring female participation in politics and business take effect in many parts of the developing world, there exist many opportunities to examine the role of women (and marginalized populations more generally) in marketing activities.

While natural experiments are fairly powerful in helping the researcher identify causal effects, and while some of the most creative work currently being done exploits all manner of natural discontinuities (see [39, 42] for fascinating examples of this genre, exploring such issues as the impact of the slave trade and migration patterns), they are by no means the only means of identifying causality. We next discuss another promising approach to the study of marketing in emerging markets.

3. Use of Randomized Controlled Trials (RCTS): Randomized controlled trials are a technique familiar in the context of medical drug testing and widely used in the laboratory in fields such as psychology but relatively unused in the field. Recent years have seen an explosion of work in economics - especially development economics - using this method. Microentrepreneurs have been studied to understand returns to their enterprises and the possible constraints to increasing investment even with attractive returns [18] and the impact of skills training $[2,35]$. The ultra-poor have been the focus of much inquiry, covering issues such as the impact of small loans, and more generally, the financial and social outcomes of microlending in general [7], the impact of health interventions such as mosquito nets [20] and deworming tablets [40], and the effect of inducements such as free bicycles on school attendance [41]. The general approach of these studies is to identify an intervention of interest, such as loans to microentrepreneurs. A suitable sample is then picked to get the 'treatment', i.e. loans. Measurements are taken (frequently via fairly detailed surveys), on both the intervention group and an equivalent group of individuals who did not get the treatment, referred to as the control group. Care is taken to 
ensure that the assignment to treatment and control groups is random. Comparing changes in the treatment group to the control group gives a clean test of whether the intervention had a significant impact or not.

An early example of this kind of work is the De Mel et al. [18] study referred to earlier. The researchers gave small loans to a set of micro-entrepreneurs in Sri Lanka; a control group did not receive any loans. Two sets of findings stand out. First, they found average real returns of roughly 55-63\% per year, which far exceeded prevailing commercial lending rates. In light of this, the puzzle is why all these micro-entrepreneurs did not undertake this capital investment themselves. Second, they found interesting heterogeneity in these returns. While entrepreneurial ability and existing financial endowments had the usual positive effect, risk aversion did not seem to matter, and, importantly, the significant positive returns were restricted to men; female-owned enterprises showed no positive returns. How can marketing help in the take-up of economically (and socially) beneficial activities? An RCT by Bertrand et al. [10] on the effects of direct mail advertising on loan takeup suggests that although marketing can indeed increase takeup, 'it is difficult to predict ex ante which specific advertising features matter most'. For example, a photo of an attractive woman in an advertisement increases loan demand by as much as a $25 \%$ reduction in interest rate. Contexts such as these offer much promise in helping marketers obtain a nuanced understanding of decision-making among the poor.

A very interesting strand of RCT work, much smaller in volume than work focused on the individual, studies the management practices of firms. The exemplar here is Bloom and van Reenen [11] who examine the effect of providing consulting help (regarding operations management, not marketing per se) to a set of medium-sized textile firms in India. A major part of their work was to come up with a classification of management practices that can then facilitate the objective scoring of firms along various dimensions. They find that the 'treatment' of 3 months of consulting resulted in an increase in productivity of $11 \%$ and that the cost of the consultancy would have been recovered in less than a year through enhanced profits.

There are a large number of firm-related questions that marketing can fruitfully study using this approach. What is the impact of marketing consulting, training, or skills on profits? Does this impact vary across firms large and small, strong and weak, experienced and inexperienced? While there is nothing methodologically that prevents this approach from being used widely in the developed world, practical considerations suggest huge barriers. It is much easier to persuade firms to participate in RCTs in emerging markets, for a host of reasons. Small incentives by Western standards can be powerful, and phase in designs (whereby firms in the treatment condition randomly receive the intervention before those in the control condition do) is quite feasible, because the interventions are more new and perceived as more attractive to the populations of interest.

The discussion so far has centred on new approaches that help the researcher identify causal mechanisms in the field more rigorously. While useful, it is the application of these techniques to new outcome variables and new explanatory variables that is likely to be of immediate relevance to marketing researchers. We turn to some examples of this now.

\section{New Outcome Variables}

To facilitate the discussion, we classify outcomes of interest as being either (i) economic, (ii) social (iii) psychological or (iv) spillover.

Economic The typical outcome variables studied in firm-level research in marketing have been variables such as sales, returns on investment, stock market returns and profits. Emerging markets research — especially research with microentrepreneurs - offers the opportunity to examine a wider set of outcomes. For example, what is the impact of marketing activities on employment growth? A question such as this is important in emerging markets, since unemployment rates of these markets can be quite high relative to many developed markets. Moreover, for methodological reasons noted earlier, it is in many ways easier to identify the effects of marketing on a wide array of economic outcomes. We can draw inspiration from studies such as Bryan et al. [12] on the impact of loans on a sample of 250 small and medium enterprises in the Philippines (how much do they grow, how is the competition that does not get these loans affected) and Hassan et al. [28] on the impact of product assortment on the performance of 350 retailers in Cairo, Egypt. Similarly, the De Mel et al. study referred to earlier was able to measure returns to investments with a relatively cheap intervention, costing less than $\$ 100$ per subject. The context is such that one has access to hundreds of small entrepreneurs and study a wide variety of firm-level economic outcomes. Moreover, because the firms have simple organizational structures (or no organizational structures at all), researchers can abstract away the effects of organizations and offer a relatively 'clean' test of the impact of marketing activities on economic outcomes.

While there is much that we do not know about what makes some micro-entrepreneurs do better than others, or even some larger firms do better than others (the Bloom et al. study referred to earlier is almost the only piece of evidence in this regard), the state of knowledge is almost as bleak (and, consequently, as hopeful in terms of research opportunities) if one considers economic outcomes such as consumption at the individual level. In contrast to the rich work on consumer 
behaviour in the developed world, we know very little about how the poor manage their expenditure and consumption. For instance, a pioneering influential study [16] points to how the very high variability of income that is common to the poor, affects every aspect of savings and consumption behaviour, and how they resort to elaborate measures to reduce the impact of this variance. If consumers experience extreme income variability, how should marketers adjust what they do by way of response? Almost anything that sheds light on the marketing lives of the poor has the potential to make a contribution.

Psychological As mentioned earlier, compressed change provides very fertile ground for observing fairly large changes in such fundamental constructs as aspirations, personality and happiness. An early working paper by Bernard and Taffesse [8] brings this out clearly. The authors showed a video to farmers that showed one of their peers taking action to achieve success in farming and business. Two control groups were shown either an entertainment video or nothing at all. A follow-up survey found that those who saw the video 'reported higher aspirations, saved more, and invested more in their children's education than the other two groups' [9].

The Jensen and Oster [34] study on cable TV is another example of significant changes in attitudes towards female empowerment. The fact that these are the only studies to look at such issues shows how much there is left to do. For instance, large-scale migration from rural to urban areas has produced a class of people who have been exposed to a dramatically different set of stimuli. We know very little about how mind sets and aspirations for these migrants differ from those who have stayed behind. And, linking this to our earlier discussion of outcomes, how do their consumption patterns change?

Social Marketing researchers have a great deal to contribute on issues pertaining to public policy and social outcomes, especially as they pertain to consumption behaviour (e.g. smoking, alcohol consumption, obesity). Emerging markets offer a much richer canvas, with the potential for research to have impact that can transform millions of lives. What kind of marketing communication, for instance, works best to encourage socially and individually desirable behaviour, such as educating girl children? Conversely, what kind of marketing communication works best to discourage undesirable behaviour such as open defecation (still practiced by roughly 500 million Indians and a major cause of health and safety problems)? What role do social networks play in helping information dissemination? How influential are key members of the social network in convincing others to adopt good practices and shun bad ones? While the role of word-of-mouth communication and key influencers has seen much recent work in marketing, emerging markets arguably offer a much richer palette of problems, both in their diversity and in their consequentiality.
A simple example illustrates the potential for such on social marketing. Ashraf et al. [4] look at how to incentivize the performance of agents recruited by non-profit public health organization in Zambia to promote HIV prevention and sell condoms. Now, it is well known from the psychology and marketing literatures that monetary rewards for tasks may result in the diminution of intrinsic motivation; to the extent that intrinsic motivation is a major reason why people probably select into organizations like the one being studied, one could imagine that explicit monetary rewards would backfire. The authors conduct an RCT, with groups of agents receiving varying levels of financial and non-financial incentives. They find that, indeed, non-financial incentives do a good job of enhancing sales. Importantly, they find that both kinds of incentives do better for people who are already more pro-social in their motivation (i.e. more intrinsically motivated to begin with). Given the long history of research in marketing with roots in both economics and psychology, these are the kinds of studies that would seem to be a natural fit for researchers in marketing.

Spillover The final class of effects is probably the least studied in marketing, but holds a lot of promise, at least judging by the few studies that exist in the literature. While most work referred to so far has focused on studying the direct effects of various shocks (cable TV, roads, migration) on individuals, at least equally important, and in most case many times more so, are the indirect effects on individuals and entire communities by way of spillovers. A simple study that uses the RCT approach brings this out clearly (Jensen Haryana). [Short description highlighting importance of spillovers]. A similar study looked at the impact of a fellowship award to secondary school students in India, albeit using a natural experiment approach [45]. They found a direct effect, in that the perceived value of education went up because of the award (mean up, variance down). However, the effects had a selective spill over on to social networks - peers did not revise their priors, while family members did perceive higher returns to education.

It is worth mentioning that while we have framed the discussion above in terms of economic, psychological, social and spillover outcomes, these categorizations are necessarily fluid, and many studies are likely to overlap across multiple categories. A good example of this is a study by Jensen [33] in the Dominican Republic, an RCT whose treatment consisted of a social marketing message to a group of students exactly what the economic returns to education were (i.e. what they could hope to earn after completing different levels of education). Because the sample in question had much lower perceived returns than what was objectively true, this intervention succeeded in changing actual behaviour in terms of school attendance, as well as aspirations in terms of what job they could do. In that sense, the study could equally have been 
classified under both the psychological and social outcome categories. And, if the study had measured effects on the family and social group, it would have been a good candidate for inclusion in the spillover category too. Exactly the same logic holds for the Ethiopian aspirations study cited earlier - the social cause there was to raise incomes in the long run for a set of very poor people, by influencing their mindsets. Further, all the studies above have focused on populations that have been little studied by marketing - the very poor, predominantly rural underclass that is such a large part of most emerging markets.

\section{New Explanatory Variables}

A lot of our earlier discussion, be it around different kinds of outcomes or more generally about the task of attributing causality, has inevitably referred to novel explanatory variables. In order not to repeat the discussion, we keep this section brief, highlighting a few important points. We find it useful to group explanatory variables that seem of special relevance to marketing research in emerging markets under three heads: (i) Marketing Information, (ii) Marketing Skills and (iii) Marketing Practices. The Jensen [32] study on Kerala fishermen is probably the best example of the impact of information provision. Opportunities in this space abound-researchers are looking into the effect of providing price information to farmers [43], information on alternative suppliers to retailers [28] and marketing messages on objective returns to schooling ([33] study in the Dominican Republic), among other topics.

The issue of providing skills and training has seen little attention in marketing, perhaps because the level of education and training is at a fairly high level in most populations studied in the developed world. In emerging markets, however, and even more forcefully for the populations we are highlighting, even the most basic marketing knowledge is often absent. This is indeed the impetus for a whole slew of training programmes for micro-entrepreneurs in many countries (South Africa, India, Peru, among others). Many basic questions remain answered (see [2]). What happens if we provide a basic marketing education to a set of micro-entrepreneurs? How big is the impact, if any, on sales and profits? And, having answered this, one can then turn to examining the heterogeneity of impact in the population; are there differences by gender or by initial endowment of wealth, ability, motivation? It should be clear that there exists a fairly obvious research agenda here for marketing researchers to tackle.

Finally, we know relatively little of the marketing practices of much of the emerging world. Some attention has rightly been focused on large companies in such markets (the massive increase in the number of cases and popular books dealing with companies in China and India is one indicator). While there are notable differences from the developed world in the marketing strategy of even such firms, in the populations that we have highlighted, the differences are often orders of magnitude greater.

Consider micro-entrepreneurs. While they are a very large proportion of the population in many emerging markets, we know almost nothing of their marketing practices. How do they price? How do they pick suppliers? Do they carry out promotions? How do they differentiate themselves from the competition? More broadly, how do they think of the future, how long is their planning horizon? A recent study ventures into this domain and attempts answers to some of these questions [28]. This study looks at micro-entrepreneurs (retailers) in a slum in Cairo, Egypt. The authors measure, among other things, the product assortment offered by each retailer, the prices charged, the supplier(s) used and promotions, if any. In addition, they attempt to measure outcomes, such as sales and footfall. This is supplemented by a survey of the retailers, incorporating attitudinal and behavioural measures. They find, among other things, that even though most stores look identical at first glance, there is a fair degree of heterogeneity in product assortment, and that retailers distinguish themselves by such simple features as the provision of credit.

Research of this kind in turn paves the way for many follow-up studies. For instance, it would be useful to understand what the biggest constraint to expansion for these retailers is - is it finance (the formal lending sector is often closed to them), is it skills (a lack of basic knowledge of marketing, of accounting), is it information (what is the competition offering, are there cheaper suppliers I can source from, are there larger trends in fashion in the city I could tap into) or is it individual factors like aspirations and motivation?

It is not an exaggeration to say that there is a very rich set of marketing-related explanatory variables that remain to be studied. Combined with an equally rich palette of outcome variables, and with the powerful tool-kit of natural experiments and RCTs, it is not unreasonable to believe that this can be the dawn of a new era of inquiry for marketing research scholars, one that lets them use their training to address issues that affect not just thousands of the reasonably affluent but millions of those in deprivation.

\section{Conclusion}

Much of the growth and much of the change that is happening in the world today is happening in emerging markets. In this article, we offer some evidence to suggest that the changes that are happening in emerging markets today are unprecedented - in scale, scope and speed - in human history. Yet, the research that is published in top marketing journals does not so far reflect these changes; instead, it reflects more the preoccupations of those living in the developed world. But phenomena that might appear marginal or unimportant in the 
developed world are pervasive and crucial in emerging markets. Important topics remain unexplored, and opportunities to make a difference through research are wasted. This situation offers numerous possibilities for new research that is both rigorous and impactful.

In this article, we highlight some opportunities for research by focusing on two phenomena that are pervasive in emerging markets but rarely studied in developed markets: marketing by micro-entrepreneurs and consumption by marginalized populations. These phenomena offer researchers in marketing the opportunity to study new outcome variables as well as new explanatory variables. Moreover, they offer researchers the ability to link explanatory variables to outcome variables cleanly and in a manner that facilitates identification of causality. As more researchers pursue these opportunities, it is possible that journals in marketing will also experience the process that is so evident in emerging markets today: compressed change.

Acknowledgments They thank Iris Steenkamp for help in the preparation of the paper, Stephen Anderson-MacDonald, Magda Hassan, Jaideep Prabhu and Shoutong Zhang for many useful discussions and John Roberts for his encouragement and invaluable input. The authors gratefully acknowledge funding from the Tony and Maureen Wheeler Chair in Entrepreneurship, the STARS Foundation and the John and Antoinette Vermilye Fund.

\section{References}

1. Alesina A, Giuliano P, Nunn N (2013) On the origins of gender roles: women and the plough. Q J Econ 128(2):469-530

2. Anderson M, Stephen RC, Bilal Z (2015) The impact of marketing (versus Finance) on business performance: insights from a randomized controlled trial in south Africa, London Business School

3. Angrist J, Krueger AB (1991) Does compulsory school attendance affect schooling and earnings? Q J Econ 106:979-1014

4. Ashraf N, Oriana B, Kelsey J (2014) No margin, no mission? A field experiment on incentives for public services delivery, J Public Econ, forthcoming

5. Banerjee A, Arun C, Esther D, Matt J (2013) The diffusion of microfinance. Science 344:6144

6. Banerjee A, Duflo E (2007) The economic lives of the poor. J Econ Perspect 21(1):141-167

7. Banerjee A, Duflo E, Goldberg N, Karlan D, Osei R, Parienté W, Shapiro J, Thuysbaert B, Udry C (2015) A multifaceted program causes lasting progress for the very poor: evidence from six countries. Science 348(6236): 1260799

8. Bernard T, Alemayehu ST (2012) Measuring aspirations: discussion and example from Ethiopia. Int Food Policy Res Inst Disc 1190

9. Bernard T, Dercon S, Taffesse AS (2011) Beyond fatalism - an empirical exploration of self-efficacy and aspirations failure in ethiopia. Centre for Study of African Economies Working Paper 3, 124

10. Bertrand M, Karlan D, Mullainathan S, Shafir E, Zinman J (2010) What's advertising content worth? Evidence from a consumer credit marketing field experiment. Q J Econ 125(1):263-306
11. Bloom N, Van Reenen J (2007) Measuring and explaining management practices across firms and nations. Q J Econ 122(4): 1351-1408

12. Bryan G, Jakiela P, Karlan D, Keniston D (2013) The impact of creditscoring on Small and Medium Enterprise (SME) lending and performance in the Philippines. Ongoing project with J-PAL

13. Brynjolfsson E, McAfee A (2014) The second machine age: work, progress, and prosperity in a time of brilliant technologies, WW Norton \& Company

14. Chandy R, Narasimhan O (2011) How micro-entrepreneurs could change the world. Bus Strateg Rev 22(1):52-55

15. Chattopadhyay R, Duflo E (2004) Women as policy makers: evidence from a randomized policy experiment in India. Econometrica 72(5):1409-1443

16. Collins D, Morduch J, Rutherford S, Ruthven O (2009) Portfolios of the poor: how the world's poor live on \$2 a Day, Princeton University Press

17. Conley T, Udry C (2010) Learning about a new technology: pineapple in Ghana, Am Econ Rev

18. De Mel S, McKenzie D, Woodruff C (2008) Returns to capital in microenterprises: evidence from a field experiment, Quarterly $\mathrm{J}$ Econ, $1329-1372$

19. Dunning T (2012) Natural experiments in the social sciences: a design-based approach, Cambridge University Press

20. Dupas $P$ (2010) Short-run subsidies and long-run adoption of new health products: evidence from a field experiment, National Bureau Econ Res, 16298

21. Dutta S (2008) The impact of improved highways on Indian firms. Working paper. http://ssrn.com/abstract $=1146606$

22. Economist (2013) When giants slow down, 27, 2013

23. Easterly W (2006) Reliving the '50s: the big push, poverty traps, and takeoffs in economic development. J Econ Dev 11(4):289-318

24. Ferguson N (2004) Empire: how Britain made the modern world. Penguin, London

25. Gandhi R, Veeraraghavan R, Toyama K, Ramprasas V (2009) "Digital Green" Participatory video for agricultural extension, Information Technologies for International Development, MIT Press.

26. Ghani E, Grover A, Kerr W (2015) Highway to success: the impact of the golden quadrilateral project for the location and performance of Indian manufacturing. Econ J. doi:10.1111/ecoj.12207

27. Ghemawat P, Altman SA (2014) DHL global connectedness index: analyzing global flows and their power to increase prosperity, DHL

28. Hassan M, Prabhu J, Chandy R, Narasimhan O (2015) The lives of micro-marketers: why do some differentiate more than others (and perform better), Judge Business School

29. International Monetary Fund (2015) World economic outlook update, 2015

30. International Telecommunications Union (2015) ICT facts and figures - the world in 2015, accessed 15 September 2015, available at: http://www.itu.int/en/ITUD/Statistics/Documents/facts/ ICTFactsFigures2015.pdf

31. Jack W, Suri T (2011) Mobile money: the economics of M-PESA, NBER Working Paper No. 16721

32. Jensen R (2007) The digital provide: information (technology), market performance, and welfare in the south Indian fisheries sector. Q J Econ 122:879-924

33. Jensen R (2010) The (perceived) returns to education and the demand for schooling. Q J Econ 125(2):515-548

34. Jensen R, Oster E (2009) The power of TV: cable television and women's status in India, Quarterly J Econ, 1057-1094

35. Karlan D, Valdivia M (2011) Teaching entrepreneurship: impact of business training on microfinance clients and institutions. Rev Econ Statistics 93(2):510-527

36. Lighting Africa (2014) Solar lighting products improve energy access for 28.5 million people in Africa, accessed 15 September 2015, 
available at: https://www.lightingafrica.org/solar-lighting-productsimprove-energy-access-for-28-5-million-people-in-africa/

37. Maddison A (2003) Development centre studies: the world economy: historical statistics. OECD, Paris

38. Mani S, Sendhil M, Elder S, Jiaying Z (2013) Poverty impedes cognitive function. Science 341(6149):976-980

39. Michalopoulos S, Papaioannou E (2013) Pre-colonial ethnic institutions and contemporary African development. Econometrica 81(1):113-152

40. Miguel E, Michael K (2003) Networks, social learning, and technology adoption: the case of deworming drugs in Kenya. Working Paper, Center for Labor Economics, University of California, Berkeley

41. Muralidharan K, Prakash N (2013) Cycling to school: increasing secondary school enrollment for girls in India. National Bureau of Economic Research, 19305
42. Nunn N, Wantchekon L (2011) The slave trade and the origins of mistrust in Africa. Am Econ Rev 101(7):3221-3252

43. Parker C, Ramdas K, Savva N (2015) Is IT enough? Evidence from a natural experiment in India's agriculture markets, London Business School

44. Rossi PE (2014) Even the rich can make themselves poor: a critical examination of IV methods in marketing applications. Mark Sci 33(5):655-672

45. Sequeira S, Spinnewijn J, Xu G (2014) Rewarding schooling success and perceived returns to education: evidence from India. London School of Economics

46. Sheth J (2011) Impact of emerging markets on marketing: rethinking existing perspectives and practices. J Mark 75:166-182

47. Viswanathan M, Rosa JA, Ruth J (2010) Exchanges in marketing systems: the case of subsistence consumer merchants in Chennai, India. J Mark 74:1-18 